
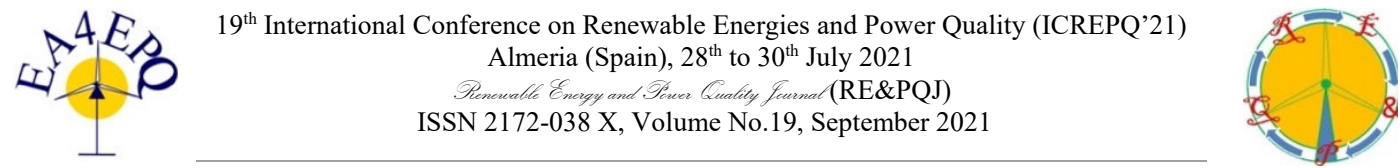

\title{
Installing green artificial reefs: a sustainable challenge
}

\author{
Alicia Munín-Doce ${ }^{1}$, Laura Castro-Santos ${ }^{2}$, Luis Carral ${ }^{3}$, Juan José Cartelle-Barros ${ }^{4}$, Carolina Camba- \\ Fabal $^{5}$, Javier Tarrío-Saavedra ${ }^{6}$
}

${ }^{1}$ Universidade da Coruña, Departamento de Enxeñaría Naval e Industrial Escola Politécnica Superior, Esteiro, 15471

Ferrol, Spain, Phone number: +34 881013468, e-mail: a.munin@udc.es

${ }^{2}$ Universidade da Coruña, Departamento de Enxeñaría Naval e Industrial Escola Politécnica Superior, Esteiro, 15471

Ferrol, Spain, Phone number: +34 881013890, e-mail: laura.castro.santos@udc.es

${ }^{3}$ Universidade da Coruña, Departamento de Enxeñaría Naval e Industrial Escola Politécnica Superior, Esteiro, 15471 Ferrol, Spain, Phone number: +34 881013254, e-mail: 1 .carral@udc.es ${ }^{4}$ Universidade da Coruña, Departamento de Economía, Facultad de Economía y Empresa, Elviña, 15008 A Coruña,
Spain, Phone number: +34 881013395, e-mail: juan.cartelle1@udc.es

${ }^{5}$ Universidade da Coruña, Departamento de Enxeñaría Naval e Industrial Escola Politécnica Superior, Esteiro, 15471

Ferrol, Spain, Phone number: +34 881013301, e-mail: carolina.camba@udc.es

${ }^{6}$ Universidade da Coruña, Departamento de Matemáticas Escola Politécnica Superior, Esteiro, 15471 Ferrol, Spain, Phone number: +34 881013208, e-mail: javier.tarrio@udc.es

\begin{abstract}
Green Artificial Reefs (GARs) are marine structures to exploit sea resources in a sustainable way (produce food resources, improve the tourism, etc.). They should be installed on the seabed, process that is not usually easy. Therefore, their installation process should be clearly defined. The aim of this paper is to propose several methods for installing a group of green artificial reefs designed in the PROARR research project. Two of these methodologies are conventional: a bulkcarrier and a special service workboat. The other technique is innovative: an autonomous vehicle. All of them offer different results in terms of maneuverability, positioning, precision and cost. This study will compare these four methods of installing green artificial reefs to improve the knowledge about this type of sustainable way of exploiting the marine resources.
\end{abstract}

Keywords. Green artificial reef, food, transport, installation

\section{Introduction}

Artificial reefs (AR) offer a refuge for different marine species [1,2]. It allows that marine animals can develop their reproduction, increasing the biodiversity of a particular sea location. AR are successful fish attractants and an significant fishery management facility [3] in areas where some species were decreased. It generates that a AR had a great social interest [4]. In addition, AR can be used to rehabilitate reef flats degraded [5], to increase the employment of an area, to improve tourism [2] or to give other uses to offshore wind [6].

The destruction of the marine habitat is one of the main causes of the decline in biodiversity and fishery resources.
The introduction of ARs into the ecosystem can be a tool to protect or restore these habitats and their declining biodiversity. However, the deployment (meaning its design, production and installation) of ARs must occur in terms of the necessary sustainability, understanding this in aspects such as; the use of materials and the processes that take place and, finally, in terms of the ecosystem created.

Sustainability in the deployment phases (materials and processes) by incorporating materials under the principle of applying the circular economy (CE) criteria, minimizing the participation of non-renewable resources and the production of technical waste. Processes, so that activities in the development of supply chains, production and distribution of ARs are carried out minimizing energy consumption and GHG emissions.

The search for sustainability finally leads to $[7,8]$ introducing the concept of ARs of the green GAR type framed within the controlled use of natural resources, typical of the EC and reduction in energy consumption and emissions. All this means reducing the size of the economic system to acceptable proportions for the biosphere [9].

The objective of the present paper is to suggest several methods for installing a group of green artificial reefs designed in the PROARR research project [10]. Two of these methodologies are conventional: a bulkcarrier and a special service workboat. Being, the other technique innovative: autonomous vehicle. All of them offer different results in terms of manoeuvrability, positioning, 
precision and cost. This study will compare these methods of installing green artificial reefs to improve the knowledge about this type of sustainable way of exploiting the marine resources.

\section{Methodology}

\section{A. Introduction}

Several methods of installing a green artificial reef can be considered:

1) Conventional methods:

1.1) Bulk carrier.

1.2) Special service workboat.

2) Innovative methods:

2.1) A barge with an autonomous vehicle.

Small vessels usually offer lifting equipment appropriate for loading and unloading at ports and piers unequipped with cranes. The diverse cargo techniques affect the number of green artificial reef units that can be stowed.

The bulk carrier has cargo holds enhanced by its relatively high draft $(5.45 \mathrm{~m})$ [1]. It has a long of $81 \mathrm{~m}$ [1]. In addition, the special service workboat has a self-propulsion system, on-deck storage and an auxiliary crane. It is shortest than the previous one, with $24 \mathrm{~m}$ and its draft is $2.3 \mathrm{~m} \mathrm{[1]}$.

\section{B. Calculation of costs}

The total cost of installing and transporting $\left(\boldsymbol{C}_{\boldsymbol{i} \& \boldsymbol{T}}\right)$ a green artificial reef is composed by the cost of transport the unit $\left(\boldsymbol{C}_{\text {TRANSPORT }}\right)$ and the cost of installing the green artificial reef $\left(\boldsymbol{C}_{\text {INSTALLING }}\right)$.

$$
C_{i \& T}=C_{T}+C_{I}
$$

The cost of transport is composed by:

- $\boldsymbol{C}_{\boldsymbol{T}_{\text {onshore }}}$ : Cost of the onshore transport.

- $\boldsymbol{C}_{T_{\text {offshore }}}$ : Cost of the offshore transport.

$$
C_{T}=C_{T_{\text {onshore }}}+C_{T_{\text {offshore }}}
$$

The cost of installing is composed by:

- $\boldsymbol{C}_{\boldsymbol{I}_{\text {onshore }}}$ : Cost of the onshore installation.

- $C_{I_{\text {offshore }}}$ : Cost of the offshore installation.

$$
C_{I}=C_{I_{\text {onshore }}}+C_{I_{\text {offshore }}}
$$

On the other hand, the cost of the onshore transport is basically, the transport of the green artificial reef units on road from the manufacturing facilities to the port. In addition, the cost of the offshore transport is the maritime transport from a particular port to the location of installing the units at sea.

Moreover, the cost of the onshore installation comprises the loading of the units in the vessel selected in the port; and the cost of the offshore installation includes other two costs: the cost of positioning the AR unit at sea and the cost of descent the units from the surface of the water to the seabed at its final position.

Fig. 1 shows the general procedure of installing and transport the AR units to their final position at sea.

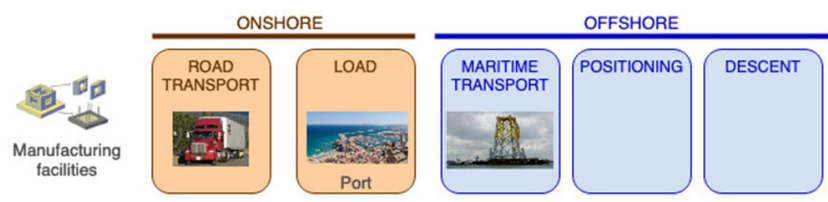

Fig. 1. General view. Source: Own elaboration.

\section{Case study}

\section{A. AR unit}

The AR considered in this study is a GAR (Green Artificial Reef) [1], where the traditional materials (cement, sand, gravel and frames) were replaced in a percentage by waste (oyster and mussel shells and eucalyptus vegetable fibers). It has been defined in the PROARR research project (Recycled Artificial Reef Project).

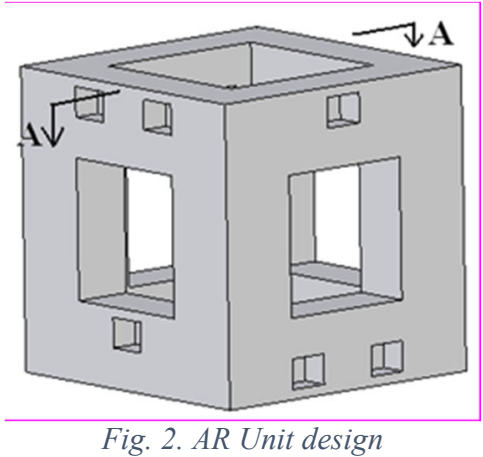

AR dimensions are $1.5 \mathrm{~m} \times 1.5 \mathrm{~m}$ at the base, and $1.5 \mathrm{~m}$ height. The total weight is 5.2 ton.

\section{B. Location selected}

The location selected to analyze the different types of methodologies for installing the AR units is the Galicia region, located in the North-West of Spain, in the Iberian Peninsula. It is composed by four areas (see Fig. 3): Rías Altas, Costa Ártabra, Costa da Morte and Rías Baixas.

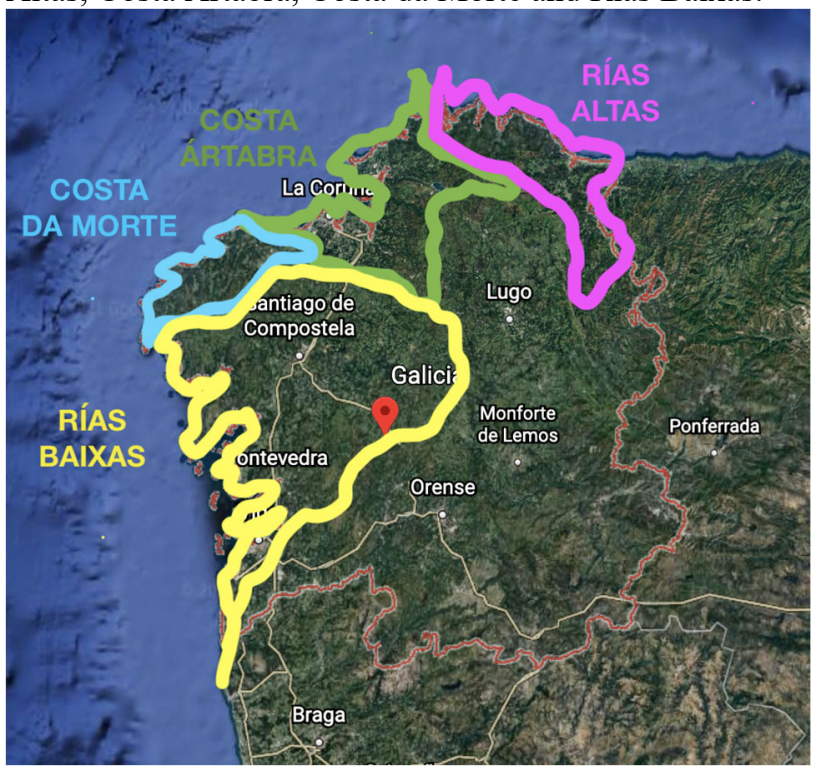

Fig. 3. Main areas studied. Source: Own elaboration using Google Earth

Each of these areas is composed by several Estuaries, each of them associated to a particular boarding port, as is shown.

Table I. Galician Estuaries considered and their respective boarding ports.

\begin{tabular}{|c|c|c|}
\hline AREA & ESTUARY & BOARDING PORT (Hj) \\
\hline \multirow{3}{*}{ Rías Altas } & Ribadeo & Ribadeo \\
\cline { 2 - 3 } & Foz & Foz \\
\cline { 2 - 3 } & Viveiro & Celeiro \\
\hline
\end{tabular}




\begin{tabular}{|c|c|c|} 
& Barqueiro & Barqueiro \\
\cline { 2 - 3 } & Ortigueira & Cariño \\
\cline { 2 - 3 } Costa Ártabra & Cedeira & Cedeira \\
\hline & Ferrol & Lorbé/Mugardos \\
\cline { 2 - 3 } & Ares & Lorbé/Sada \\
\cline { 2 - 3 } & Betanzos & Lorbé/Sada \\
\cline { 2 - 3 } Costa da Morte & O Burgo & Lorbé/Oza \\
\hline & Corme/Laxe & Corme \\
\cline { 2 - 3 } & Camariñas & Muxía \\
\cline { 2 - 3 } & Corcubión & Corcubión/Brens \\
\cline { 2 - 3 } & Muros & Muros \\
\cline { 2 - 3 } & Noia & O Freixo/Muros \\
\hline \multirow{5}{*}{ Rías Baixas } & Arousa & Vilanova de \\
& Pontevedra & Portonovo \\
\cline { 2 - 3 } & Aldán & Cangas \\
\cline { 2 - 3 } & Vigo & Cangas \\
\hline
\end{tabular}

\section{Results}

Firstly, results for time and costs for the installation method 1.1. are shown in table II.

Table II. Time and cost results for method 1.1.

\begin{tabular}{|c|c|c|}
\hline $\begin{array}{c}\text { BOARDING } \\
\text { PORT (Hj) }\end{array}$ & $\begin{array}{c}\text { TOTAL TIME } \\
(\text { days })\end{array}$ & $\begin{array}{c}\text { TOTAL COST } \\
(€)\end{array}$ \\
\hline Ribadeo & 5 & 45226 \\
\hline Foz & 1 & 9674 \\
\hline Celeiro & 15 & 134685 \\
\hline Barqueiro & 6 & 53961 \\
\hline Cariño & 4 & 36262 \\
\hline Cedeira & 10 & 89844 \\
\hline Lorbé/Mugardos & 20 & 181449 \\
\hline Lorbé/Sada & 8 & 72575 \\
\hline Lorbé/Sada & 11 & 96412 \\
\hline Lorbé/Oza & 3 & 29227 \\
\hline Corme & 12 & 107924 \\
\hline Muxía & 10 & 89996 \\
\hline Corcubión/Brens & 13 & 116838 \\
\hline Muros & 26 & 239788 \\
\hline O Freixo/Muros & 26 & 239788 \\
\hline $\begin{array}{c}\text { Vilanova de } \\
\text { Arousa/Ribeira }\end{array}$ & 59 & 538863 \\
\hline Portonovo & 50 & 449120 \\
\hline Cangas & 20 & 183447 \\
\hline Cangas & 40 & 359310 \\
\hline
\end{tabular}

Moreover, results for time and costs for the installation method 1.2. are shown in table III.

Table III. Time and cost results for method 1.2.

\begin{tabular}{c|c|c|}
\hline BOARDING & $\begin{array}{c}\text { TOTAL TIME } \\
\text { PORT }(\mathrm{Hj})\end{array}$ & $\begin{array}{c}\text { TOTAL COST } \\
(€)\end{array}$ \\
\hline
\end{tabular}

\begin{tabular}{|c|c|c|}
\hline Ribadeo & 17 & 6367 \\
\hline Foz & 4 & 1630 \\
\hline Celeiro & 52 & 18508 \\
\hline Barqueiro & 21 & 7473 \\
\hline Cariño & 14 & 5144 \\
\hline Cedeira & 35 & 12380 \\
\hline Lorbé/Mugardos & 92 & 33123 \\
\hline Lorbé/Sada & 28 & 10274 \\
\hline Lorbé/Sada & 49 & 17423 \\
\hline Lorbé/Oza & 11 & 4916 \\
\hline Corme & 41 & 14906 \\
\hline Muxía & 35 & 12459 \\
\hline Corcubión/Brens & 45 & 16103 \\
\hline Muros & 122 & 42686 \\
\hline O Freixo/Muros & 122 & 42686 \\
\hline Vilanova de & & 138754 \\
\hline Arousa/Ribeira & 412 & 115685 \\
\hline Portonovo & 343 & 26659 \\
\hline Cangas & 70 & 63768 \\
\hline Cangas & 183 & \\
\hline & & \\
\hline
\end{tabular}

Finally, results for time and costs for the installation method 1.3. are shown in table IV.

Table IV. Time and cost results for method 1.3.

\begin{tabular}{|c|c|c|c|}
\hline $\begin{array}{c}\text { BOARDING } \\
\text { PORT (Hj) }\end{array}$ & $\begin{array}{c}\text { N. } \\
\text { UNIT } \\
(\text { ARj })\end{array}$ & $\begin{array}{c}\text { TOTAL } \\
\text { TIME } \\
\text { (days) }\end{array}$ & $\begin{array}{c}\text { TOTAL } \\
\text { COST }(€)\end{array}$ \\
\hline Ribadeo & 180 & 9 & 35249 \\
\hline Foz & 180 & 9 & 41530 \\
\hline Celeiro & 180 & 9 & 41465 \\
\hline Barqueiro & 180 & 9 & 41168 \\
\hline Cariño & 180 & 9 & 41327 \\
\hline Cedeira & 180 & 9 & 41305 \\
\hline $\begin{array}{c}\text { Lorbé/Mugardo } \\
\text { s }\end{array}$ & 240 & 12 & 57044 \\
\hline Lorbé/Sada & 180 & 9 & 41870 \\
\hline Lorbé/Sada & 240 & 12 & 55492 \\
\hline Lorbé/Oza & 180 & 9 & 43114 \\
\hline Corme & 180 & 9 & 41504 \\
\hline Muxía & 180 & 9 & 41448 \\
\hline $\begin{array}{c}\text { Corcubión/Bre } \\
\text { ns }\end{array}$ & 180 & 9 & 41485 \\
\hline Muros & 240 & 12 & 55894 \\
\hline $\begin{array}{c}\text { O } \\
\text { Freixo/Muros }\end{array}$ & 240 & 12 & 55894 \\
\hline $\begin{array}{c}\text { Vilanova de } \\
\text { Arousa/Ribeira }\end{array}$ & 360 & 18 & 84308 \\
\hline Portonovo & 360 & 18 & 83931 \\
\hline Cangas & 180 & 10 & 45312 \\
\hline Cangas & 240 & 12 & 56269 \\
\hline
\end{tabular}


Of the three methodologies analysed for the positioning of the reef complex (barge and drone, service work boat and mini bulkcarrier), the one that offers a reduced positioning time and greater versatility is that of the barge and the drone, because they are capable of operate at any depth. Draft limitations in some of the estuaries make it impossible to use large vessels to transport the AR units. Also, this method presents reasonable time operation and cost does not skyrocket compared to the other two.

\section{Conclusion}

This work has proposed several methods for installing a group of green artificial reefs designed in the PROARR research project. Two of these methodologies were conventional: a bulkcarrier and a special service workboat. The other technique was innovative: an autonomous vehicle.

All of them offer different results in terms of manoeuvrability, positioning, precision and cost. The barge + drone is the best method in terms of time operation, draft and versatility. Draft limitations in some of the estuaries make it impossible to use large vessels to transport the AR units.

The estuaries with more number of AR units are Vilanova de Arousa/Ribeira and Portonovo, with a total of 360 AR units, which represents a total time of 18 days, being their costs $84,308 €$ and $83,931 €$ respectively.

This study will establish a first step in overall analysis of the installation process of green artificial reefs in the Galician shore, which will make a sustainable way of exploiting the marine resources.

\section{Acknowledgement}

The authors gratefully acknowledge the financial support from the regional government of Galicia, Xunta de Galicia, through the project CN-10MMA003CT. This study was also funded through the collaboration agreement between Xunta de Galicia, Universidade da Coruña and the Universidade da Coruña Foundation (FUAC) to give continuity to the previous project.

\section{References}

[1] L. Carral, J.J.C. Barros, H.C. Fidalgo, C.C. Fabal, A.M. Doce, Greenhouse gas emissions and energy consumption of coastal ecosystem enhancement programme through sustainable artificial reefs in Galicia, Int. J. Environ. Res. Public Health. 18 (2021) 119. doi:10.3390/ijerph18041909.

[2] X. Zheng, T. Ji, S.M. Easa, Y. Ye, Evaluating feasibility of using sea water curing for green artificial reef concrete, Constr. Build. Mater. 187 (2018) 545-552. doi:10.1016/j.conbuildmat.2018.07.140.

[3] J.A. Bohnsack, D.L. Sutherland, Artificial reef research: a review with recommendations for future priorities., Bull. Mar. Sci. 37 (1985) 11-39.

[4] L. Carral, J.C. Alvarez-Feal, J. Tarrio-Saavedra, M.J. Rodriguez Guerreiro, J.Á. Fraguela, Social interest in developing a green modular artificial reef structure in concrete for the ecosystems of the Galician rías, J. Clean. Prod. (2018).

doi:10.1016/j.jclepro.2017.11.252.

[5] S. Clark, A.J. Edwards, Use of artificial reef structures to rehabilitate reef flats degraded by coral mining in the Maldives, Bull. Mar. Sci. 55 (1994) 724-744.

[6] O. Langhamer, Artificial reef effect in relation to offshore renewable energy conversion: State of the art, Sci. World J. 2012 (2012). doi:10.1100/2012/386713.

[7] L. Carral, J.C. Alvarez-Feal, J. Tarrio-Saavedra, M.J. Rodriguez Guerreiro, J.Á. Fraguela, Social interest in developing a green modular artificial reef structure in concrete for the ecosystems of the Galician rías, J. Clean. Prod. 172 (2018) 1881-1898.

doi:10.1016/j.jclepro.2017.11.252.

[8] X. Huang, Z. Wang, Y. Liu, W. Hu, W. Ni, On the use of blast furnace slag and steel slag in the preparation of green artificial reef concrete, Constr. Build. Mater. 112 (2016) 241-246.

doi:10.1016/j.conbuildmat.2016.02.088.

[9] B. Suárez-Eiroa, E. Fernández, G. Méndez-Martínez, D. Soto-Oñate, Operational principles of circular economy for sustainable development: Linking theory and practice, J. Clean. Prod. 214 (2019) 952-961. doi:10.1016/j.jclepro.2018.12.271.

[10] L. Carral, C.C. Fabal, M.I.L. Galdo, M.J. RodríguezGuerreiro, J.J.C. Barros, Assessment of the materials employed in green artificial reefs for the galician estuaries in terms of circular economy, Int. J. Environ. Res. Public Health. 17 (2020) 1-24. doi:10.3390/ijerph17238850. 